\title{
Mineralogy of the Rincón Blanco selenide occurrence, La Rioja, Argentina
}

\author{
María Florencia MÁRQUEZ-ZAVALÍA ${ }^{1,2^{*}}$, Miguel Ángel GALLISKI ${ }^{1}$, Pavel ŠKÁCHA ${ }^{3,4}$, \\ Ivo MACEK ${ }^{3}$, Jiří SEJKORA ${ }^{3}$, Zdeněk DOLNÍĆEK ${ }^{3}$
}

\author{
${ }^{1}$ IANIGLA, CCT-Mendoza (CONICET), Avda. A. Ruiz Leal s/n, Parque San Martin, CC330, 5500 Mendoza, Argentina; \\ mzavalia@mendoza-conicet.gov.ar \\ ${ }^{2}$ Mineralogía y Petrología, F.A.D., Universidad Nacional de Cuyo, Centro Universitario, 5502 Mendoza, Argentina \\ ${ }^{3}$ Department of Mineralogy and Petrology, National Museum, Cirkusová 1740, 19300 Prague 9, Czech Republic \\ ${ }^{4}$ Hornické Muzeum Př́bram, Náměstí Hynka Kličky 293, 26101 Př́bram, Czech Republic \\ * Corresponding author
}

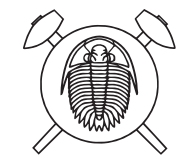

Rincón Blanco is a small selenide occurrence situated to the WNW of Jagüé, a small town of the General Sarmiento department, La Rioja province, Argentina. This occurrence, also called El Chire in recent years, is located $\left(28^{\circ} 35^{\prime} 46.10^{\prime \prime} \mathrm{S}\right.$, $68^{\circ} 44^{\prime} 35.78^{\prime \prime W}, 3120 \mathrm{~m}$. a. s. 1.) in the Precordillera environment, to the furthermost southwestern corner of the selenium ore district of Los Llantenes, defined as one of the representative metallogenic belts of the Gondwanic episodes. The selenide minerals occur as veinlets up to few centimeters or as patches or fine inclusions, widespread in calcite. We have identified eleven hypogene Se-bearing minerals (naumannite, tiemannite, chrisstanleyite, jagüéite, eucairite, clausthalite, fischesserite, umangite, athabascaite, berzelianite and bellidoite) mainly associated with gold, silver, hematite and various supergene minerals, including malachite, chalcomenite, and molybdomenite. The paragenesis should have formed from low temperature $\left(<133^{\circ} \mathrm{C}\right)$, neutral to mildly alkaline $\mathrm{pH}$ and highly oxidizing fluids with increasing sulfur fugacity. The country-rock, rich in graptolite-fauna, could be considered, at least in part, the source for the Se and associated metals forming the minerals of this paragenesis, although this hypothesis has yet to be tested.

Keywords: selenide mineralization, chrisstanleyite, jagüéite, fischesserite, gold, Rincón Blanco, La Rioja, Argentina Received: 5 October 2020; accepted: 12 January 2021; handling editor: J. Plášil

\section{Introduction}

There are two regions with selenide mineralizations known in Argentina since the $19^{\text {th }}$ century, located in Mendoza and La Rioja provinces.

The first one consists of a small occurrence, known since the 1860s (Domeyko 1867), currently has no selenide minerals at sight in the two adits that are still opened. This occurrence, known as Cacheuta, is the type occurrence of achávalite and molybdomenite. The main hypogene selenides recognized by two of authors (MFMZ, MAG) in old samples are clausthalite, klockmannite, eskebornite, tyrrellite, trogtalite and naumannite. Samples from this small mine are part of collections from various parts of the world and, based on some of them, Grundmann and Foster (2018) published a revision of its mineralogy.

The second region with selenium mineralization, at $\mathrm{La}$ Rioja province, is more prominent and consists of several districts with many old and inactive mines. Among those districts, the most known and worked, especially during the $19^{\text {th }}$ century and the first half of the $20^{\text {th }}$, are Los Llantenes and Cerro Cacho; the others are Sierra de Umango, Sañogasta and Famatina (Brodtkorb 1999).

The main aim of this paper is to describe in detail the mineralogy of Rincón Blanco, a small selenide occur- rence situated at the farthest southwestern corner of Los Llantenes district or in between Los Llantenes and Cerro Cacho districts (Fig. 1).

\section{Geological settings}

This small selenide occurrence, named initially as Rincón Blanco (White Nook) by locals, was later called El Chire (Paar et al. 2004) without any explanation for the name change, so we will continue to use the original name. The selenide occurrence owes its name to the Puesto Rincón Blanco, which was located in the vicinity, and where the caretaker of the area used to live.

Rincón Blanco itself $\left(28^{\circ} 35^{\prime} 46.10^{\prime \prime} \mathrm{S}, 68^{\circ} 44^{\prime} 35.78^{\prime \prime} \mathrm{W}\right.$, 3120 m. a. s. 1.) is situated to the WNW of Jagüé, a small town of the General Sarmiento department, La Rioja province, Argentina (Fig. 1). It can be reached by driving 39 $\mathrm{km}$ to the west along the road RN-76, and then walking for about $3 \mathrm{~km} \mathrm{SW}$ from the road. Until the 1960s, there were several small paths and trails that do not exist nowadays, all washed away by the rains and the passage of time. This occurrence is located to the SE of the selenium ore district of Los Llantenes (Guerrero 1969; Angelelli 1984; Brodtkorb 1999; Brodtkorb and Crosta 2010; Cardó et 


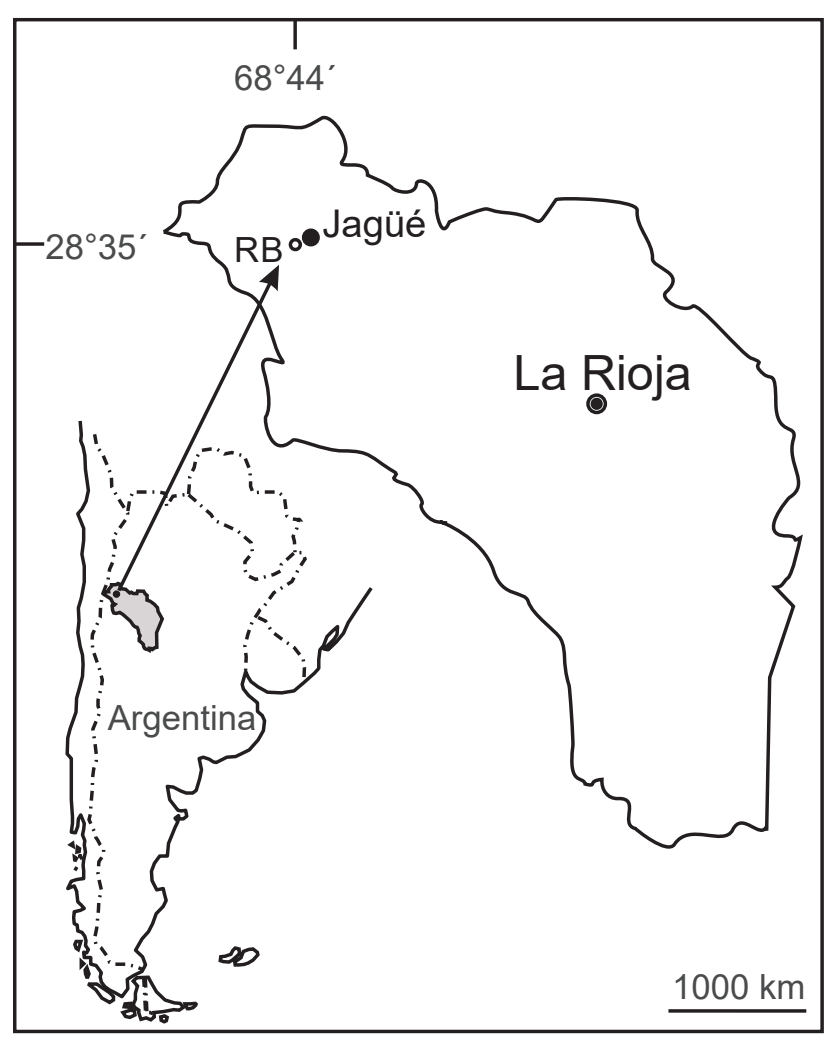

Fig. 1 Schematic map of Argentina, with Rincón Blanco (RB) location.

al. 2015, and references therein), maybe representing the furthermost southwestern corner of that district, in the Precordillera environment. Cardó et al. (2015) defined the Los Llantenes Belt as one of the representative metallogenic belts of the Gondwanic episodes. The lithology of the area is represented by magnesian limestone with intercalations of Ordovician shale from the Río Bonete Group, composed of the Las Damas and Cerro Cóndor Formations, which were intruded by dioritic bodies and dikes of andesite porphyries of Silurian-Devonian age. The Neopaleozoic sedimentary rocks of the Cerro Minitas (Carboniferous) and Patquía (Permian) Formations overlay discordantly all the above mentioned rocks. Modern debris (Quaternary) partially covers the aforementioned lithostratigraphic units (Guerrero 1969; Angelelli 1984). Aceñolaza et al. (1971) mention that the $\mathrm{Cu}-\mathrm{Se}$ with $\mathrm{Hg}$ mineralizations of the Precordillera de Jagüé, of which Rincón Blanco would be the southernmost occurrence, are included in the slate, shale and limestone from the Río Bonete Group.

\section{Methodology}

\subsection{Samples and optical investigations}

Fieldwork at the Rincón Blanco occurrence was conducted in 2016. Samples were obtained directly from the outcrops either inside the gallery or outside along the fracture that hosts the mineralization, where thin veinlets were found.

Microscopic examinations of the ore minerals were undertaken on 65 standard polished sections, using a Leica DM2500 P reflected light polarizing microscope with a Leica DFC295 camera.

\subsection{Chemical composition}

Chemical analyses were performed with a Cameca SX-100 electron microprobe (National Museum in Prague, Czech Republic) operating in the wavelengthdispersion mode, with an accelerating voltage of $25 \mathrm{kV}$, a sample current of $20 \mathrm{nA}$ and a beam diameter of 1 to $5 \mu \mathrm{m}$; counting time of $20 \mathrm{~s}$ was spent for the peak and $10 \mathrm{~s}$ for each background. The used standards, analytical lines and average detection limits (given in wt. \%) were as follows: $\mathrm{Cl}$ (halite, $\left.K_{\alpha}, 0.05\right), \mathrm{Ag}\left(\mathrm{Ag}, L_{\alpha}, 0.13\right), \mathrm{Hg}$ (HgTe, $M_{\alpha}, 0.13$ and 1.23 for minerals with $\mathrm{Cl}$ ), $\mathrm{Pb}(\mathrm{PbS}$, $\left.M_{\alpha}, 0.13\right), \mathrm{Sb}\left(\mathrm{Sb}_{2} \mathrm{~S}_{3}, L_{\alpha}, 0.07\right)$, Te (PbTe, $\left.L_{\alpha}, 0.08\right), \mathrm{Sn}(\mathrm{Sn}$, $\left.L_{\alpha}, 0.06\right), \mathrm{S}, \mathrm{Cu}$ (chalcopyrite, $\left.K_{\alpha}, 0.02,0.5\right), \mathrm{Co}\left(\mathrm{Co}, K_{\alpha}\right.$, $0.05), \mathrm{Ni}\left(\mathrm{Ni}, K_{\alpha}, 0.04\right), \mathrm{Fe}$ (pyrite, $\left.K_{\alpha}, 0.04\right), \mathrm{Zn}(\mathrm{ZnS}$, $\left.K_{\alpha}, 0.09\right)$, Pd (Pd, $\left.L_{\alpha}, 0.05\right)$, Pt (Pt, $\left.M_{\alpha}, 0.15\right)$, Rh (Rh, $\left.L_{\alpha}, 0.08\right), \mathrm{Bi}\left(\mathrm{Bi}_{2} \mathrm{Se}_{3}, M_{\beta}, 0.12\right), \mathrm{Cd}\left(\mathrm{CdTe}, L_{\alpha}, 0.03\right), \mathrm{Tl}$ (TlBrI, $\left.L_{\alpha}, 0.25\right)$, Se (PbSe, $\left.L_{\beta}, 0.12\right)$ ), As (NiAs, $\left.L_{\beta}, 0.14\right)$, Ge (Ge, $\left.L_{\alpha}, 0.08\right)$, In (InAs, $\left.L_{\alpha}, 0.05\right), \mathrm{Mn}\left(\mathrm{Mn}, K_{\alpha}, 0.06\right)$, $\mathrm{Ga}\left(\mathrm{GaAs}, L_{\alpha}, 0.01\right), \mathrm{Au}\left(\mathrm{Au}, M_{\alpha}, 0.16\right), \mathrm{K}$ (sanidine, $K_{\alpha}$, 0.03 ), Ba (baryte, $L_{\alpha}, 0.05$ ) and P, Ca (fluorapatite, $K_{\alpha}$, $0.01,0.02)$. The contents of other than the mentioned elements were below the limits of detection. All samples were carefully checked before analyses, under the highest magnification, to avoid analyzing grains containing small inclusions present in the analyzed phase, so analyzed spots were selected from homogeneous, inclusion-free areas. The data were reduced using the $P A P$ routine (Pouchou and Pichoir 1985).

Mineral names abbreviations, when possible, follow The Canadian Mineralogist list of symbols for rock- and ore-forming minerals (https:/canminportal.files.wordpress.com/2018/03/symbols2.pdf), heavily inspired by the original listing of Kretz (1983).

\section{Results}

\subsection{Rincón Blanco mineralogy}

Rincón Blanco Se-rich mineralization fill fractures in the Cerro Minitas Formation (Guerrero 1969), which, according to Aceñolaza (1971), could be correlated with the Volcán Formation (Furque 1958). The Cerro Minitas Formation is composed of alternated levels of sandstones (including arkoses and greywackes) and shales. The fos- 
sil content described by Aceñolaza (1971) indicates a fluviopaludal environment at the base of the sequence and a marine environment at the upper levels. Based on that, and the shale-sandstone intercalated sequences, Aceñolaza (1971) assumed that the environmental conditions point to a coastal area or one near the coast.

The Rincón Blanco Se-bearing vein was mined during the 1960s, leaving behind a short gallery $(<5 \mathrm{~m})$ following the vein, which increases its thickness from 1 to $2 \mathrm{~cm}$ near the entrance of the gallery (Fig. 2a) to up to $15 \mathrm{~cm}$ inside (Fig. 2b), with an average of 4 to $5 \mathrm{~cm}$. Just the small dumps disappearing in very steep terrain were found.

The veins and veinlets showing pinch and swell structure and rough symmetrical banding (Fig. 2) are composed of calcite with hypogene selenides associated with gold, silver, hematite and various supergene minerals, including malachite, chalcomenite and molybdomenite. The selenide minerals occur as veinlets up to few centimeters wide or as patches or fine inclusions, widespread in calcite, in some features similar to the famous historical Swedish selenium-deposit Skrikerum (Bindi and Pratesi 2005; Jonsson et al. 2014), but lacking Tl-bearing minerals in its paragenesis.

The order of description of the minerals will follow their apparent abundance observed on-site and in the hand

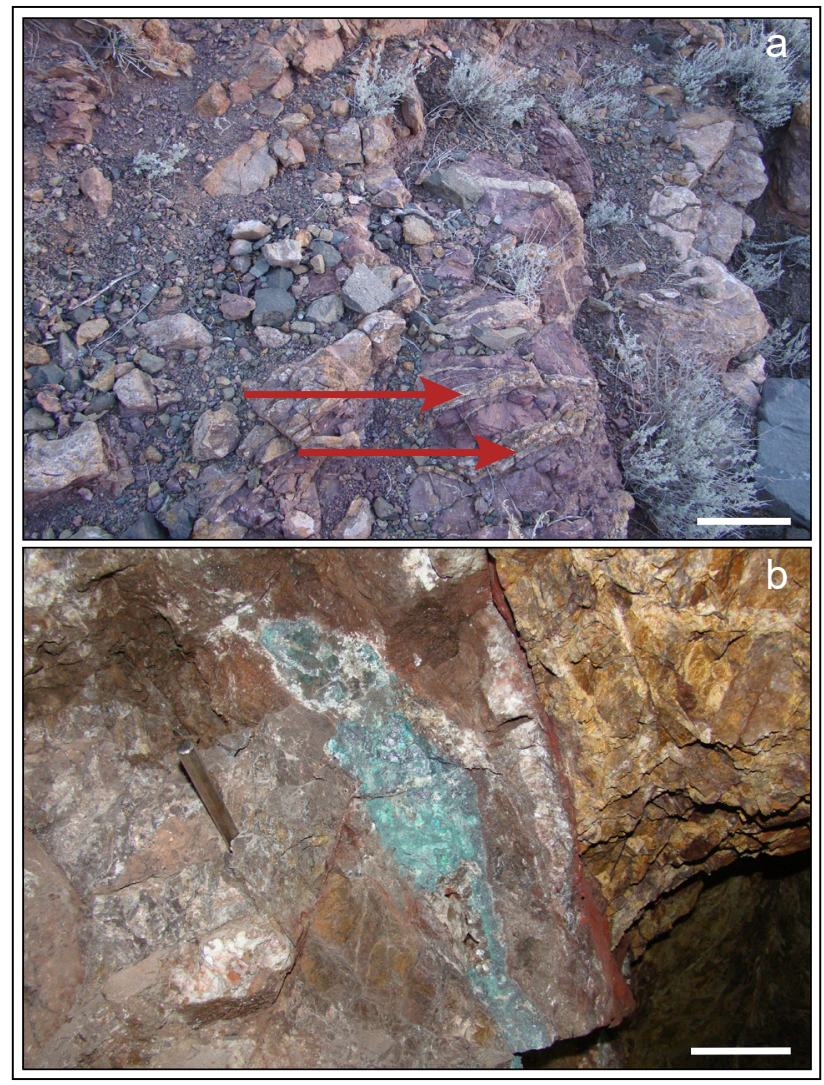

Fig. 2 a - Outcrop outside the gallery, showing the thin calcite-selenides veinlets. $\mathbf{b}$ - Selenide vein inside the gallery. Scale bars $=15 \mathrm{~cm}$.
Tab. 1 Relative abundance of the described Se-bearing minerals

\begin{tabular}{|c|c|c|}
\hline Mineral & Formula & Relative abundance \\
\hline Naumannite & $\mathrm{Ag}_{2} \mathrm{Se}$ & ++ \\
\hline Tiemannite & $\mathrm{HgSe}$ & ++ \\
\hline Chrisstanleyite & $\mathrm{Ag}_{2} \mathrm{Pd}_{3} \mathrm{Se}_{4}$ & + \\
\hline Jagüéite & $\mathrm{Cu}_{2} \mathrm{Pd}_{3} \mathrm{Se}_{4}$ & + \\
\hline Clausthalite & $\mathrm{PbSe}$ & $*$ \\
\hline Eucairite & $\mathrm{CuAgSe}$ & * \\
\hline Fischesserite & $\mathrm{Ag}_{3} \mathrm{AuSe}_{2}$ & * \\
\hline Umangite & $\mathrm{Cu}_{3} \mathrm{Se}_{2}$ & $*$ \\
\hline Athabascaite & $\mathrm{Cu}_{5} \mathrm{Se}_{4}$ & o \\
\hline Berzelianite & $\mathrm{Cu}_{2-x} \mathrm{Se}(x \approx 0.12)$ & o \\
\hline Bellidoite & $\mathrm{Cu}_{2} \mathrm{Se}$ & o \\
\hline Chalcomenite & $\mathrm{Cu}\left(\mathrm{Se}^{4+} \mathrm{O}_{3}\right) \cdot 2 \mathrm{H}_{2} \mathrm{O}$ & + \\
\hline Molybdomenite & $\mathrm{PbSe}^{4+} \mathrm{O}_{3}$ & + \\
\hline
\end{tabular}

Relative abundance: ++ very abundant, + abundant, ${ }^{*}$ scarce; ${ }^{\circ}$ rare

specimens and the polished sections. Table 1 lists the Sebearing minerals described in this work in Rincón Blanco. Tables 2 to 5 show one representative analysis, and the average and standard deviation for each analyzed mineral.

\subsubsection{Calcite}

This is the main gangue mineral of these veins and veinlets. It is found in interlocked crystals with massive, granular, and feathery textures filling fractures and in cavities developing prismatic crystals with scalenohedral terminations up to several $\mathrm{mm}$ in size, always intimately associated with the Serich minerals. The color of calcite is generally colorless to white but is often tinged or covered by a thin, uneven green patina due to oxidation of the surrounding copper minerals.

\subsubsection{Naumannite, $\mathrm{Ag}_{2} \mathrm{Se}$}

Naumannite, along with tiemannite, are the main selenide minerals present in this location. Naumannite occurs as discontinuous layers or clusters of grains of millimeter to centimeter sizes (Fig. 2b), generally interstitial in calcite (Fig. 3a). It also occurs in patches (Fig. 3b) from tens of micrometers up to a few centimeters and finely widespread in calcite and other selenides; less frequently occurs displaying pseudo-graphic textures in the host calcite. It also displays shredded and skeletal textures. Intergrowths of tiemannite and naumannite are frequent and one mineral dominates over the other in different areas (Fig. 3b, c), sometimes coexisting in areas of centimeter dimensions. Its chemical composition (Tab. 2) sometimes includes $\mathrm{Cu}$ (up to $0.10 a p f u$ ) and, exceptionally, up to $0.04 a p f u \mathrm{Hg}$; small amounts of S, up to 0.03 apfu could be present. The empirical formula of naumannite, based on an average of 23 chemical analyses, can be expressed on the basis of 3 atoms per formula unit (apfu) as: $\left(\mathrm{Ag}_{1.99} \mathrm{Cu}_{0.02}\right)_{\Sigma 2.01} \mathrm{Se}_{0.98}$. 
Tab. 2 Representative and average compositions of naumannite, tiemannite, chrisstanleyite and jagüéite

\begin{tabular}{|c|c|c|c|c|c|c|c|c|c|c|c|c|}
\hline & \multicolumn{3}{|c|}{ Naumannite } & \multicolumn{3}{|c|}{ Tiemannite } & \multicolumn{3}{|c|}{ Chrisstanleyite } & \multicolumn{3}{|c|}{ Jagüéite } \\
\hline & 2047 & $\begin{array}{c}\text { Average } \\
n=23\end{array}$ & $\mathrm{SD}$ & 2046 & $\begin{array}{c}\text { Average } \\
n=20\end{array}$ & $\mathrm{SD}$ & 2052 & $\begin{array}{c}\text { Average } \\
n=34\end{array}$ & $\mathrm{SD}$ & 2083 & $\begin{array}{c}\text { Average } \\
n=22\end{array}$ & $\mathrm{SD}$ \\
\hline \multicolumn{13}{|c|}{ wt. $\%$} \\
\hline $\mathrm{Cu}$ & bdl. & 0.38 & 0.7 & bdl. & 0.50 & 0.7 & 2.06 & 2.47 & 0.6 & 16.52 & 15.09 & 1.2 \\
\hline $\mathrm{Pd}$ & bdl. & 0.00 & & bdl. & 0.00 & & 37.42 & 38.03 & 0.5 & 41.32 & 41.20 & 0.8 \\
\hline $\mathrm{Ag}$ & 73.11 & 72.65 & 1.2 & bdl. & 0.30 & 0.5 & 22.40 & 21.75 & 1.0 & 2.08 & 2.99 & 1.1 \\
\hline $\mathrm{Hg}$ & bdl. & 0.21 & 0.5 & 71.02 & 70.52 & 1.0 & 0.85 & 0.50 & 0.4 & bdl. & 0.15 & 0.2 \\
\hline $\mathrm{S}$ & bdl. & 0.03 & 0.1 & bdl. & 0.00 & & bdl. & 0.00 & & bdl. & 0.00 & \\
\hline $\mathrm{Se}$ & 26.43 & 26.23 & 0.5 & 28.83 & 29.17 & 0.4 & 36.94 & 37.42 & 0.3 & 40.36 & 40.33 & 0.7 \\
\hline Total & 99.54 & & & 99.85 & & & 99.67 & & & 100.28 & & \\
\hline \multicolumn{13}{|l|}{ apfu } \\
\hline $\mathrm{Cu}$ & 0.00 & 0.02 & & 0.00 & 0.02 & & 0.27 & 0.33 & & 1.98 & 1.84 & \\
\hline $\mathrm{Pd}$ & 0.00 & 0.00 & & 0.00 & 0.00 & & 2.98 & 2.99 & & 2.97 & 2.99 & \\
\hline $\mathrm{Ag}$ & 2.01 & 1.99 & & 0.00 & 0.01 & & 1.76 & 1.69 & & 0.15 & 0.21 & \\
\hline $\mathrm{Hg}$ & 0.00 & 0.00 & & 0.98 & 0.96 & & 0.04 & 0.02 & & 0.00 & 0.01 & \\
\hline $\mathrm{S}$ & 0.00 & 0.00 & & 0.00 & 0.00 & & 0.00 & 0.00 & & 0.00 & 0.00 & \\
\hline $\mathrm{Se}$ & 0.99 & 0.98 & & 1.02 & 1.01 & & 3.96 & 3.97 & & 3.90 & 3.95 & \\
\hline Total & 3.00 & 3.00 & & 2.00 & 2.00 & & 9.00 & 9.00 & & 9.00 & 9.00 & \\
\hline
\end{tabular}

SD - standard deviation; bdl. - below detection limit

\subsubsection{Tiemannite, HgSe}

Tiemannite is chiefly associated with naumannite, although, in general, it is less abundant; it is easily recognizable under the microscope due to its brown tint and the lower quality of the polished surface, compared to naumannite. Its more frequent presentations are interstitial fillings in calcite and associated with naumannite (Fig. 3a), as inclusions or intergrowths with naumannite, either in blebs (Fig. 3c), lamellae, or developing myrmekitic textures (Fig. 3d). Sometimes this mineral occurs in acicular crystals developing arborescent habits (Fig. 3e, f). The chemical composition of tiemannite (Tab. 2) sometimes includes small quantities of $\mathrm{Cu}$ and $\mathrm{Ag}$ (up to 0.08 and $0.04 a p f u$, respectively); its empirical formula, based on an average of 20 chemical analyses and on the base of 2 apfu is: $\left(\mathrm{Hg}_{0.96} \mathrm{Cu}_{0.02} \mathrm{Ag}_{0.01}\right)_{\Sigma 0.99} \mathrm{Se}_{1.01}$.

\subsubsection{Chrisstanleyite, $\mathrm{Ag}_{2} \mathrm{Pd}_{3} \mathrm{Se}_{4}$}

This rare mineral (Paar et al. 1998, 2004) is frequent in this locality and mainly occurs closely associated with jagüéite, included in calcite or malachite, and as irregular inclusions $(<20 \mu \mathrm{m}$, Fig. $3 \mathrm{~g})$ or in small cavities, up to $200 \mu \mathrm{m}$ (Fig. 3h), in tiemannite. Besides main Ag

Tab. 3 Representative and average compositions of clausthalite, eucairite and fischesserite.

\begin{tabular}{|c|c|c|c|c|c|c|c|c|c|}
\hline & \multicolumn{3}{|c|}{ Clausthalite } & \multicolumn{3}{|c|}{ Eucairite } & \multicolumn{3}{|c|}{ Fischesserite } \\
\hline & 2042 & $\begin{array}{c}\text { Average } \\
n=9\end{array}$ & $\mathrm{SD}$ & 2047 & $\begin{array}{c}\text { Average } \\
n=27\end{array}$ & $\mathrm{SD}$ & 2044 & $\begin{array}{c}\text { Average } \\
n=7\end{array}$ & $\mathrm{SD}$ \\
\hline \multicolumn{10}{|l|}{ wt. $\%$} \\
\hline $\mathrm{Cu}$ & bdl. & 0.41 & 0.9 & 24.25 & 24.32 & 1.5 & 1.91 & 2.45 & 1.0 \\
\hline $\mathrm{Ag}$ & bdl. & 0.28 & 0.0 & 43.81 & 43.70 & 1.8 & 47.99 & 51.51 & 4.0 \\
\hline $\mathrm{Au}$ & bdl. & 0.00 & & bdl. & 0.00 & & 26.26 & 24.43 & 3.5 \\
\hline $\mathrm{Hg}$ & bdl. & 0.40 & 1.1 & bdl. & 0.18 & 0.5 & 0.60 & 0.75 & 0.2 \\
\hline $\mathrm{Pb}$ & 71.99 & 70.67 & 1.3 & bdl. & 0.00 & & bdl. & 0.00 & \\
\hline $\mathrm{Se}$ & 28.05 & 28.29 & 0.9 & 31.74 & 31.14 & 0.7 & 23.15 & 20.79 & 2.2 \\
\hline Total & 100.04 & & & 99.80 & & & 99.91 & & \\
\hline \multicolumn{10}{|l|}{ apfu } \\
\hline $\mathrm{Cu}$ & 0.00 & 0.02 & & 0.96 & 0.97 & & 0.20 & 0.25 & \\
\hline $\mathrm{Ag}$ & 0.00 & 0.01 & & 1.02 & 1.03 & & 2.95 & 3.16 & \\
\hline $\mathrm{Au}$ & 0.00 & 0.00 & & 0.00 & 0.00 & & 0.88 & 0.82 & \\
\hline $\mathrm{Hg}$ & 0.00 & 0.01 & & 0.00 & 0.00 & & 0.02 & 0.02 & \\
\hline $\mathrm{Pb}$ & 0.99 & 0.96 & & 0.00 & 0.00 & & 0.00 & 0.00 & \\
\hline $\mathrm{Se}$ & 1.01 & 1.01 & & 1.01 & 1.00 & & 1.94 & 1.74 & \\
\hline Total & 2.00 & 2.00 & & 3.00 & 3.00 & & 6.00 & 6.00 & \\
\hline
\end{tabular}

SD - standard deviation; bdl. - below detection limit 
and $\mathrm{Pd}$, it contains minor $\mathrm{Hg}$ (up to $0.08 a p f u$ ) and $\mathrm{Cu}$ (0.22-0.51 apfu); a determined range of $\mathrm{CuAg}_{-1}$ substitution (Fig. 4) corresponds to published data (Paar et al. 2004). The empirical formula of chrisstanleyite (average of 34 analyses) on the base of 9 apfu is $\left(\mathrm{Ag}_{1.69} \mathrm{Cu}_{0.33}\right)_{\Sigma 2.02}$ $\left(\mathrm{Pd}_{2.99} \mathrm{Hg}_{0.02}\right)_{\Sigma 3.01} \mathrm{Se}_{3.97}$.

\subsubsection{Jagüéite, $\mathrm{Cu}_{2} \mathrm{Pd}_{3} \mathrm{Se}_{4}$}

Rincón Blanco (El Chire) is the type locality for this mineral (Paar et al. 2004). It occurs as small $(<50 \mu \mathrm{m})$, anhedral to subhedral inclusions in naumannite (Fig. 5a, b), and also intimately intergrown with chrisstanleyite, developing myrmekitic textures and lamellae up to $8 \mu \mathrm{m}$ thick (Fig. $3 \mathrm{~h})$. A jagüéite grain was also found with a thin intergranular veinlet of tiemannite (Fig. 5c). The chemical composition of jagüéite shows beside main $\mathrm{Cu}$ and Pd (Tab. 2) minor Hg (up to 0.03 apfu) and Ag contents in the range 0.14-0.44 apfu (Fig. 4). Its empirical formula (average of 22 analyses), on the base of 9 apfu is $\left(\mathrm{Cu}_{1.84} \mathrm{Ag}_{0.21}\right)$ ${ }_{\Sigma 2.05}\left(\mathrm{Pd}_{2.99} \mathrm{Hg}_{0.01}\right)_{\Sigma 3.00} \mathrm{Se}_{3.95}$.

\subsubsection{Clausthalite, PbSe}

Clausthalite is relatively sparse in this locality. It occurs mainly as finely disseminated grains $(<$ $30 \mu \mathrm{m})$ in calcite, associated with other selenide minerals, e.g., eucairite (Fig. $5 \mathrm{~d}$ ), or as rare and more significant (up to $500 \mu \mathrm{m}$ ), subhedral crystals (Fig. 5e) or patches (Fig. 5f) in tiemannite, partly replaced by molybdomenite. Its chemical

Fig. 3 (a to f: photomicrography; g, h: BSE images) a - naumannite (Nau) and tiemannite (Tmn) in calcite (Cal). b naumannite associated with tiemannite. c - tiemannite intergrown with naumannite. d-myrmekitic textures of tiemannite in naumannite. $\mathbf{e}, \mathbf{f}-$ acicular crystals of tiemannite with arborescent habits. $\mathbf{g}, \mathbf{h}-$ chrisstanleyite (Csl) in tiemannite. Scale bars equal to $50 \mu \mathrm{m}$. composition (Tab. 3) shows a slight enrichment in silver, up to $0.01 \mathrm{apfu}$; a few analyses show up to $0.12 \mathrm{apfu}$ of $\mathrm{Cu}$; based on the average of 9 analyses, its empirical formula $(a p f u=2)$ is $\left(\mathrm{Pb}_{0.96} \mathrm{Cu}_{0.02} \mathrm{Ag}_{0.01}\right)_{\Sigma 0.99} \mathrm{Se}_{1.01}$.

\subsubsection{Eucairite, CuAgSe}

This mineral is scarce and generally occur as small grains $(<1$ to $20 \mu \mathrm{m}$ on average) widespread in calcite (Fig. $5 \mathrm{~d}$ ); some of the grains have small $(<1 \mu \mathrm{m})$, anhe-

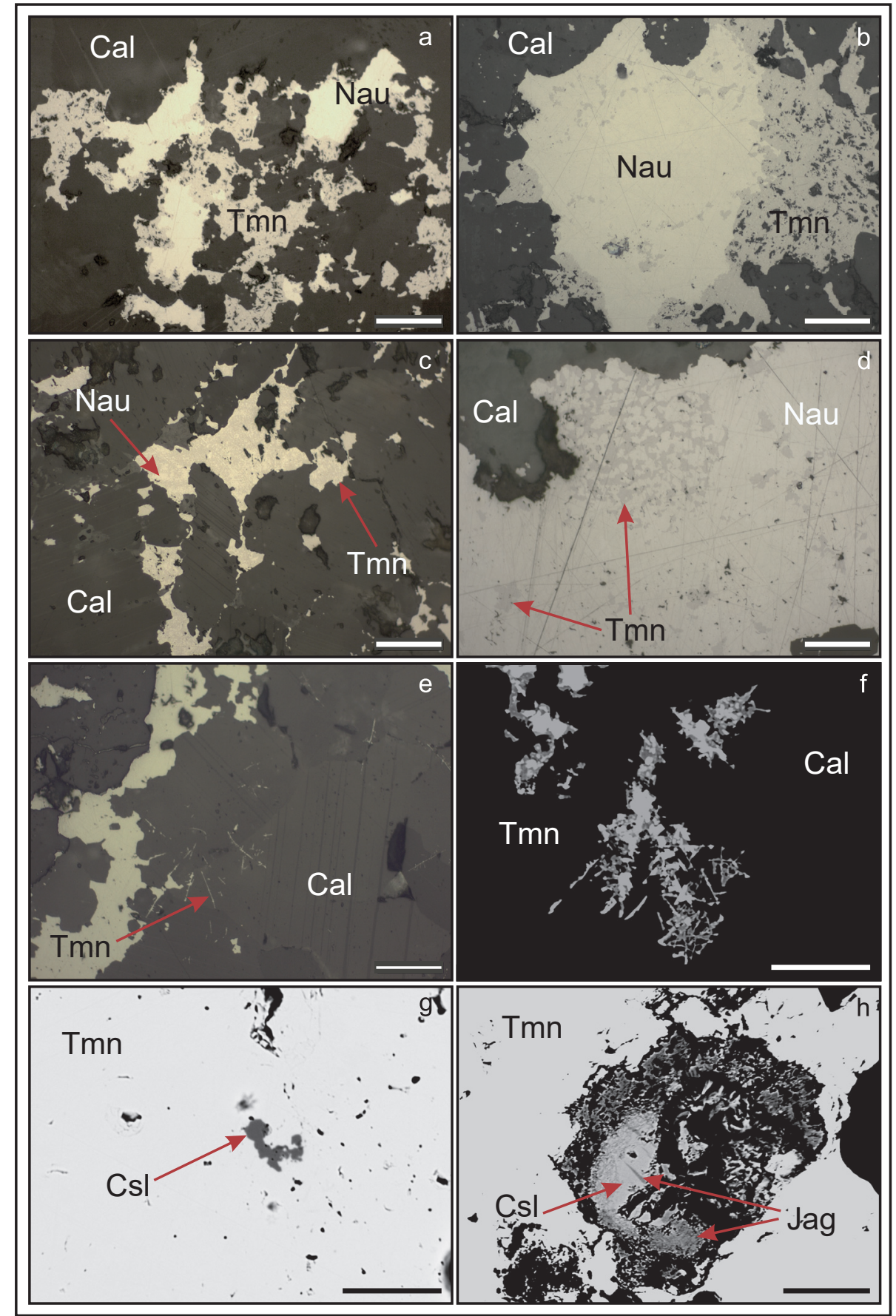




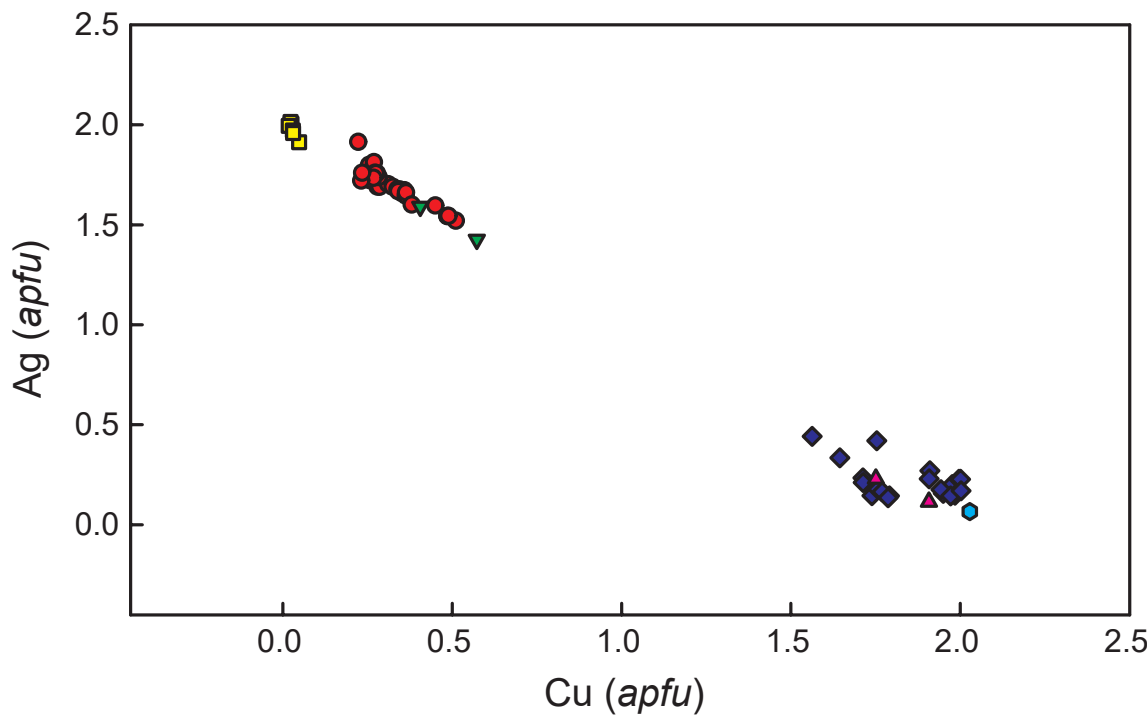

- chrisstanleyite, Rincón Blanco (this paper)

$\nabla$ chrisstanleyite, Rincón Blanco (Paar et al. 2004)

- chrisstanleyite, Hope's Nose (Paar et al. 1998), Pilbara (Nickel 2002)

- jagüéite, Rincón Blanco (this paper)

$\Delta \quad$ jagüéite, Rincón Blanco (Paar et al. 2004)

- jagüéite, Pilbara (Nickel 2002)
Fig. 4 The Cu vs. Ag (apfu) graph for chisstanleyite and jagüéite. dral, rounded inclusions of naumannite, displaying a naumannite disease-like texture (Fig. $5 \mathrm{~g}$, h) with naumannite crystallographically oriented in eucairite. Its chemical composition (Tab. 3) shows elevated $\mathrm{Hg}$ contents up to 0.02 apfu. The empirical formula, based on the average of 27 analyses $(a p f u=3)$, is $\mathrm{Cu}_{0.97} \mathrm{Ag}_{1.03} \mathrm{Se}_{1.00}$.

\subsubsection{Fischesserite, $\mathrm{Ag}_{3} \mathrm{AuSe}_{2}$}

Fischesserite, the selenide member of the petzite group (Johan et al. 1971; Strunz and Nickel 2001, in Bindi and Cipriani 2004), occurs as anhedral, rounded to elongated grains, generally up to $30 \mu \mathrm{m}$ in size (Fig. 6a). Under

Tab. 4 Representative and average compositions of umangite, athabascaite, berzelianite and bellidoite.

\begin{tabular}{|c|c|c|c|c|c|c|c|c|c|c|c|c|c|c|c|}
\hline & \multicolumn{3}{|c|}{ Umangite (S-poor) } & \multicolumn{3}{|c|}{ Umangite (S-rich) } & \multicolumn{3}{|c|}{ Athabascaite } & \multicolumn{3}{|c|}{ Berzelianite } & \multicolumn{3}{|c|}{ Bellidoite } \\
\hline & 2042 & $\begin{array}{c}\text { Average } \\
n=3\end{array}$ & $\mathrm{SD}$ & 2049 & $\begin{array}{c}\text { Average } \\
n=3\end{array}$ & $\mathrm{SD}$ & 2075 & $\begin{array}{c}\text { Average } \\
n=15\end{array}$ & $\mathrm{SD}$ & 2044 & $\begin{array}{c}\text { Average } \\
n=5\end{array}$ & $\mathrm{SD}$ & 2078 & $\begin{array}{c}\text { Average } \\
n=6\end{array}$ & $\mathrm{SD}$ \\
\hline \multicolumn{16}{|l|}{ wt. $\%$} \\
\hline $\mathrm{Fe}$ & bdl. & 0.00 & & bdl. & 0.02 & 0.0 & bdl. & 0.04 & 0.2 & bdl. & 0.00 & 0.0 & 4.04 & 3.69 & 0.6 \\
\hline $\mathrm{Cu}$ & 51.57 & 51.42 & 0.1 & 52.97 & 56.06 & 2.9 & 53.07 & 52.90 & 3.2 & 60.88 & 60.70 & 0.4 & 60.73 & 60.79 & 0.5 \\
\hline $\mathrm{Ag}$ & bdl. & 0.22 & 0.4 & 4.31 & 1.87 & 2.2 & 2.64 & 2.53 & 2.6 & 0.27 & 0.28 & 0.2 & bdl. & 0.00 & \\
\hline $\mathrm{Hg}$ & bdl. & 0.00 & & 0.60 & 0.20 & 0.3 & bdl. & 0.33 & 0.5 & bdl. & 0.00 & & bdl. & 0.00 & \\
\hline $\mathrm{S}$ & 0.18 & 0.12 & 0.1 & 6.30 & 6.81 & 0.5 & 6.37 & 6.74 & 0.9 & 5.08 & 5.35 & 0.2 & 5.60 & 5.86 & 0.8 \\
\hline $\mathrm{Se}$ & 45.46 & 45.14 & 0.4 & 34.82 & 32.97 & 2.2 & 36.86 & 37.06 & 1.6 & 33.16 & 32.65 & 0.4 & 30.45 & 30.36 & 0.9 \\
\hline Total & 97.21 & & & 99.00 & & & 98.94 & & & 99.39 & & & 100.82 & & \\
\hline apfu & $=5$ & & & $=5$ & & & $=9$ & & & $(\mathrm{Se}+$ & S) $=1$ & & $(\mathrm{Se}+$ & 5) $=1$ & \\
\hline $\mathrm{Fe}$ & 0.00 & 0.00 & & 0.00 & 0.00 & & 0.00 & 0.01 & & 0.00 & 0.00 & & 0.13 & 0.12 & \\
\hline $\mathrm{Ag}$ & 0.00 & 0.01 & & 0.13 & 0.06 & & 0.14 & 0.14 & & 0.00 & 0.00 & & 0.00 & 0.00 & \\
\hline $\mathrm{Au}$ & 0.00 & 0.00 & & 0.00 & 0.00 & & 0.00 & 0.00 & & 0.00 & 0.00 & & 0.00 & 0.00 & \\
\hline $\mathrm{Hg}$ & 0.00 & 0.00 & & 0.01 & 0.00 & & 0.00 & 0.01 & & 0.00 & 0.00 & & 0.00 & 0.00 & \\
\hline $\mathrm{S}$ & 0.02 & 0.01 & & 0.65 & 0.69 & & 1.17 & 1.23 & & 0.27 & 0.29 & & 0.31 & 0.32 & \\
\hline $\mathrm{Se}$ & 2.07 & 2.06 & & 1.46 & 1.36 & & 2.75 & 2.75 & & 0.73 & 0.71 & & 0.69 & 0.68 & \\
\hline Total & 5.00 & 5.00 & & 5.00 & 5.00 & & 9.00 & 9.00 & & 2.66 & 2.65 & & 2.83 & 2.80 & \\
\hline
\end{tabular}

SD - standard deviation; bdl. - below detection limit 
the microscope, it is pinkish gray, isotropic, and is commonly associated with tiemannite, and sometimes with naumannite, with frequent thin $(1-2 \mu \mathrm{m})$ veinlets of gold (Fig. 6b). The chemical composition of this mineral (Tab. 3) shows, beside the main elements, $\mathrm{Cu}$ and $\mathrm{Hg}$ contents up to 0.43 and $0.04 a p f u$, respectively.

\subsubsection{Umangite, $\mathrm{Cu}_{3} \mathrm{Se}_{2}$}

Umangite, like eucairite, is scarce but well represented in most samples. It occurs as small grains, generally smaller than $10 \mu \mathrm{m}$, widespread in calcite (Fig. 6c, d) with the other selenides and sometimes with gold. Based on its chemical composition (Tab. 4) two types of umangite can be distinguished. The first is S-poor umangite with only local contents of $\mathrm{Ag}$ and $\mathrm{S}$ up to 0.02 apfu (Fig. 7a) and empirical formula calculated from the average of 3 analyses on the base of 5 apfu $\left(\mathrm{Cu}_{2.92} \mathrm{Ag}_{0.01}\right)_{\Sigma 2.93}\left(\mathrm{Se}_{2.06} \mathrm{~S}_{0.01}\right)$ ${ }_{\Sigma 2.07}$ The second is S-rich umangite, which shows, besides Se and $\mathrm{Cu}$, the participation of $\mathrm{S}$ up to 0.73 apfu (Fig. 7a); the similar range of $\mathrm{SeS}_{-1}$ substitution in umangite was reported by Wallis (1994) from the Tilkerode uranium deposit and by Škácha et al. (2017) from the Príbram uranium district. Minor Ag (up to 0.13 apfu) and $\mathrm{Hg}$ (up to 0.01 apfu), as same as traces of Fe are

Fig. 5 (a, g: photomicrography; rest: BSE images) a, b - jagüéite (Jag) and tiemannite included in naumannite. $\mathbf{c}$ - grains of jagüéite in calcite; note in the insert the thin veinlet of tiemannite in jagüéite. d - eucairite (Euc) and clausthalite (Clt) in calcite; one of the grains of clausthalite partially replaced by eucairite. $\mathbf{e}-$ crystal of clausthalite included in and, incipiently, replacing tiemannite (the contact is enhanced by the better polish acquired by clausthalite); clausthalite is being replaced by molybdomenite (mbd). f - anhedral grain of clausthalite, partly replaced by molybdomenite. $\mathbf{g}$ - eucairite, naumannite and tiemannite included and filling interstitial spaces in calcite. $\mathbf{h}$ - detail of the previous image showing the tiemannite disease-like texture in eucairite. Scale bars equal to $50 \mu \mathrm{m}$. also present. The empirical formula of this umangite type, calculated from the average of 3 analyses and on the base of 5 apfu is $\left(\mathrm{Cu}_{2.88} \mathrm{Ag}_{0.06}\right)_{\Sigma 2.94}\left(\mathrm{Se}_{1.36} \mathrm{~S}_{0.69}\right)_{\Sigma 2.05}$.

\subsubsection{Athabascaite, $\mathrm{Cu}_{5} \mathrm{Se}_{4}$}

This mineral is disseminated in calcite and malachite, locally with chalcomenite, as flakes (up to $20 \mu \mathrm{m}$ ) with threadbare texture (Fig. 6e, f) along with the other selenides. It can be easily recognized for its grayish-blue color, strong pleochroism, and an extreme anisotropy with

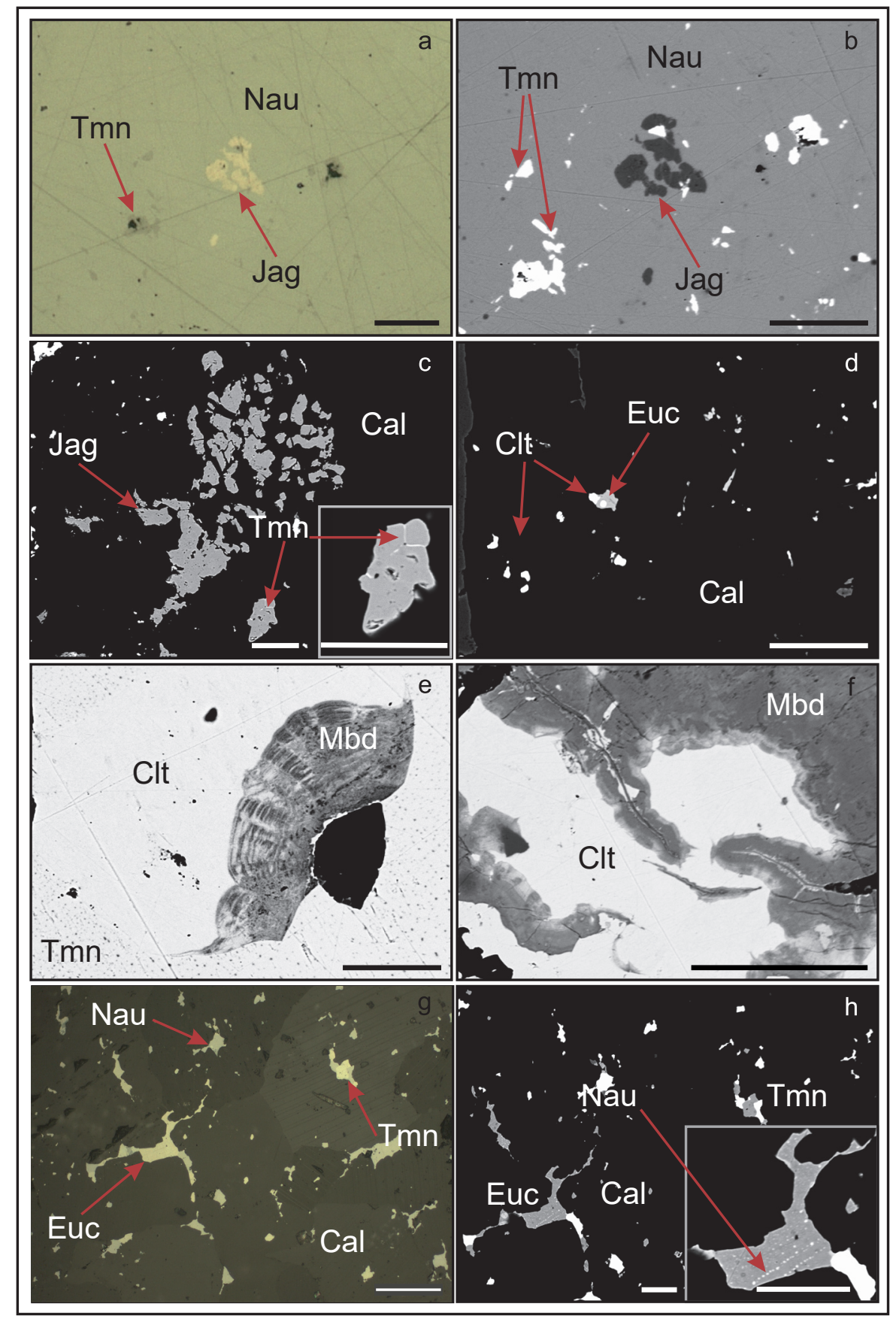


yellowish polarizing colors that become more orange when the polars are partly crossed. The chemical composition of athabascaite (Tab. 4) is represented by the cation/anion ratio in the range 1.17-1.34 (based on 15 analyses). The studied mineral grains are probably forming very fine (submicroscopic) intergrowths with other $\mathrm{Cu}$ selenides, which may be the reason for the observed non-stoichiometry (Fig. 7b). The cation part of the formula contains minor Ag (up to $0.44 \mathrm{apfu}$ ), and locally also $\mathrm{Fe}, \mathrm{Au}$ and $\mathrm{Hg}$, and the dominant $\mathrm{Cu}$. The anion part features a significant $\mathrm{SeS}_{-1}$ substitution; sulfur contents attain a range of $0.90-1.45$

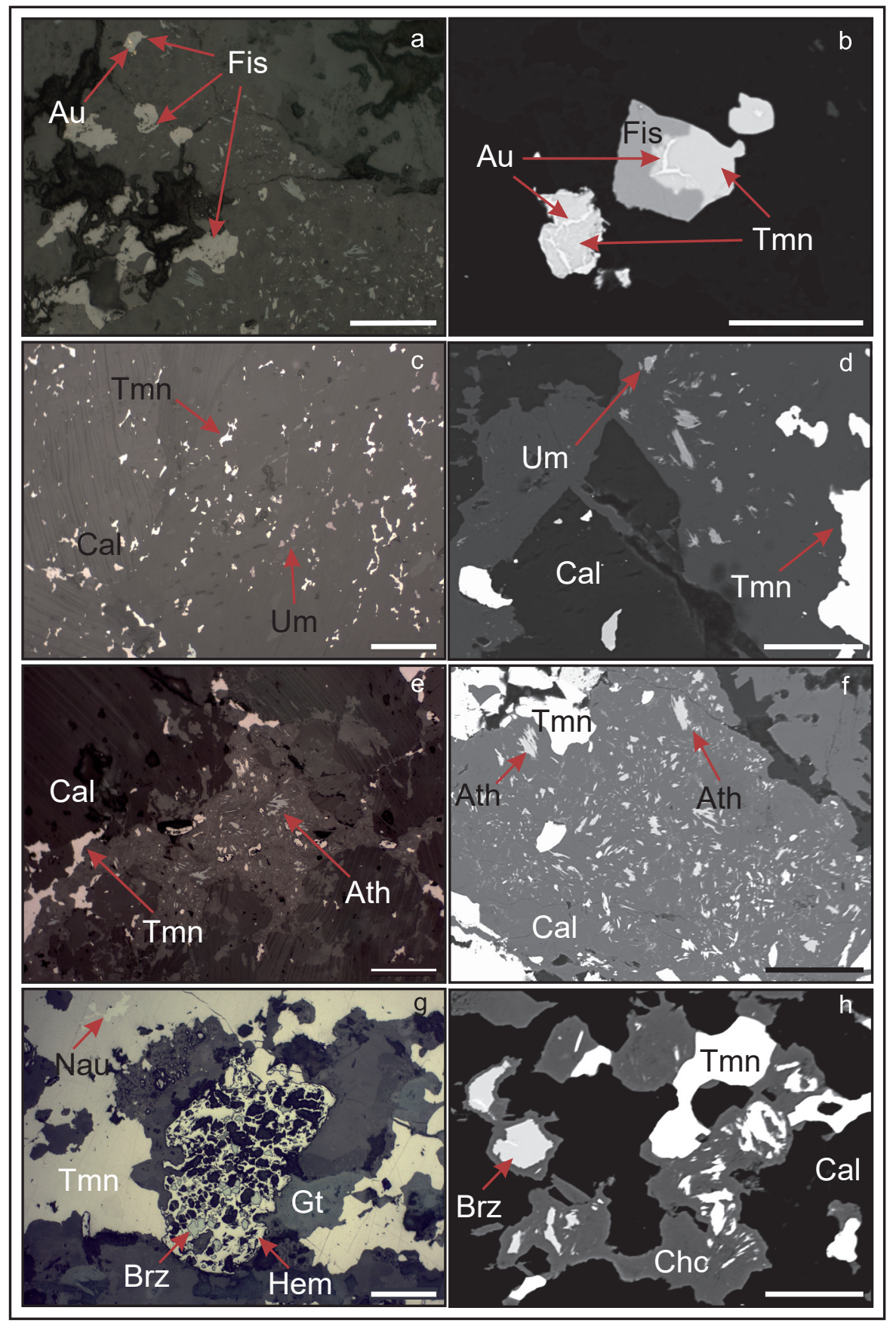

apfu (Fig. 7a). These results are similar to the ones obtained by Pirard and Hatert (2008) in samples from the Musonoï mine, Democratic Republic of Congo and Škácha et al. (2017) in athabascaite from the Príbram ore district, Czech Republic. The empirical formula of athabascaite from Rincón Blanco, calculated on an average of 15 analyses based on 9 apfu is $\left(\mathrm{Cu}_{4.87} \mathrm{Ag}_{0.14} \mathrm{Hg}_{0.01}\right)_{\Sigma 5.02}\left(\mathrm{Se}_{2.75} \mathrm{~S}_{1.23}\right)_{\Sigma 3.98}$.

\subsubsection{Berzelianite, $\mathrm{Cu}_{2-\mathrm{x}} \mathrm{Se}$}

Berzelianite occurs as small (up to $15 \mu \mathrm{m}$ ) anhedral, rounded inclusions in calcite, among the other selenides; it was also found as inclusions in hematite (Fig. 6g) and also partially replaced by chalcomenite (Fig. 6h). Although berzelianite is present in small grains, it can be distinguished easily from athabascaite due to its isotropy. The determined $x$-value from the empirical formula for studied berzelianite, in the range 0.33 0.37 (average 0.35 ), is close to the published $\mathrm{Cu}$-poor berzelianites from the Př́bram uranium ore district (Škácha et al. 2017). Sulfur is consistently present in concentrations in the range of 0.27-0.30 apfu (Fig. 7a). Such sulfur for selenium substitution has been described by Harris et al. (1970a), Förster et al. (2004) or Škácha et al. (2017). They all reported that the increased content of sulfur does not affect the mineral's optical properties, but it is reflected in decrease of the unit-cell parameters. The empirical formula, based on $\mathrm{Se}+$ $\mathrm{S}=1$ apf $u$ and an average of 5 analyses, is $\mathrm{Cu}_{1.65}\left(\mathrm{Se}_{0.71} \mathrm{~S}_{0.29}\right)_{\Sigma 1.00}$.

Fig. 6 (a, c, e, g: photomicrography; rest: BSE images). a - fischesserite (Fis) grains in calcite; some of them associated with gold $(\mathrm{Au})$. b - fischesserite replacing tiemannite; note the thin veinlets of gold crisscrossing tiemannite that do not continue into fischesserite. c, $\mathbf{d}$ - umangite (Um) and tiemannite embedded in calcite. $\mathbf{e}, \mathbf{f}$ - athabascaite embedded in calcite. $\mathbf{g}$ - berzelianite (Brz) in hematite (Hem). $\mathbf{h}$ - berzelianite, associated with tiemannite; partial to total replacement by chalcomenite (Chc). Scale bars equal to $50 \mu \mathrm{m}$. 


\subsubsection{Bellidoite, $\mathrm{Cu}_{2} \mathrm{Se}$}

This mineral is scarce in the studied specimens and, generally, it occurs in small isolated grains (about $10 \mu \mathrm{m}$ on average; Fig. 8a) or, less typically, associated with berzelianite from which, despite its small size, can be easily distinguished due to its creamy color and anisotropy. The $x$-value of the formula $\mathrm{Cu}_{2-x} \mathrm{Se}$ is for studied bellidoite about 0.20 (range $0.16-0.27$ ). This value is higher in comparison with data reported $(x=0.05)$ for bellidoite from the type occurrence (De Montreuil 1975) and comparable with bellidoite from the Příbram ore district ( $x$ up to 0.22; Škácha et al. 2017). The cation part of the formula beside $\mathrm{Cu}$ contains minor $\mathrm{Fe}$ (up to 0.13 apfu); similar contents (up to 0.06 apfu) were also described for bellidoite from Př́bram (Škácha et al. 2017). In the anion part of bellidoite from Rincón Blanco, Se is partly substituted by $\mathrm{S}$ in the range $0.30-0.39$, with average 0.32 apfu (Fig. 7a). The range of this substitution is unusual; a total absence or only low contents of $\mathrm{S}$ (up to 0.07 apfu) are characteristic for all published analyses of bellidoite from Habří (De Montreuil 1975), Tumiñico (Paar et al. 2002), Př́bram (Škácha et al. 2017) and Olympic Dam Mine (Owen et al. 2018). Considering that berzelianite and other $\mathrm{Cu}$-selenides in this paragenesis show a similar S-rich character, it appears to be characteristic of this occurrence. The empirical formula of this mineral, calculated from the average of 6 chemical analyses based on $1(\mathrm{Se}+\mathrm{S})$ apfu, is: $\left(\mathrm{Cu}_{1.69} \mathrm{Fe}_{0.12}\right)_{\Sigma 1.81}\left(\mathrm{Se}_{0.68} \mathrm{~S}_{0.32}\right)_{\Sigma 1.00}$.

\subsubsection{Hematite}

This mineral is well represented in the veins and occurs in mil-

Fig. 7 a - Se (apfu) versus S (apfu) showing the distribution of athabascaite, berzelianite, bellidoite and umangite, and the extent of S occupancy in the Se site. $\mathbf{b}-\mathrm{Cu}+\mathrm{Ag}+\mathrm{Hg}$ (at. \%) vesus $\mathrm{Se}$ $+\mathrm{S}$ (at. \%), showing the distribution of the four copper selenides from Rincón Blanco. limeter-sized subhedral to anhedral crystals widespread in calcite and frequently associated with (or replaced by) berzelianite (Fig. 6g).

\subsubsection{Gold}

Gold is ubiquitous in the veins; it has been found in micrometer- to millimeter-sized irregular clusters of grains, isolated in calcite (Fig. 8b), as well as in thin veinlets in naumannite associated with fischesserite (Fig. 6b) or surrounding that mineral (Fig. 8c). The fineness of the analyzed grains varies in the range of 861 to 887 , with an average of 874 . Its chemical composition (Tab. 5) also shows contents of Ag, $\mathrm{Hg}$ and $\mathrm{Cu}$ up to $0.18,0.02$ and 0.01 apfu, respectively.
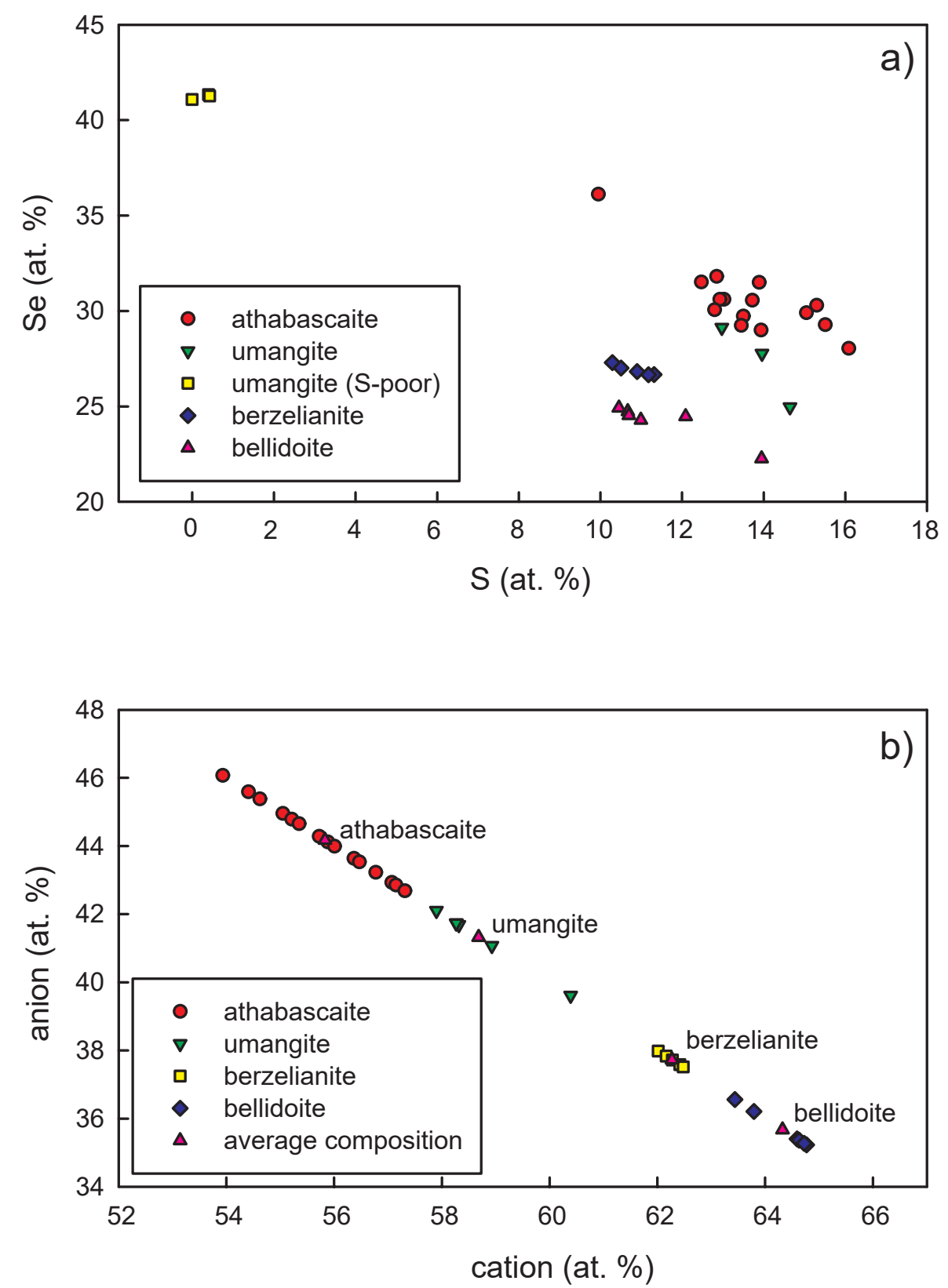


\subsubsection{Silver}

Silver has been found in grains that usually reach smaller sizes than gold, but it is also widespread in the veins. It occurs in irregular grains or groups of diverse grain sizes $(<1$ to several hundreds of $\mu \mathrm{m})$. In reflected polarized light, the grains are white with a pinkish tint and acquire bad polish, and, generally, part of them have been lost during the polishing process (Fig. 8d). It generally occurs bordering or included in naumannite. The chemical analy- ses gave low totals due to the poorly polished surface of the grains and showed the presence of $\mathrm{Cu}$ and absence of $\mathrm{Au}, \mathrm{Hg}, \mathrm{Pd}$ and $\mathrm{Cl}$ (Tab. 5). Some more chemical analyses were carried out in a mineral similar to the described silver grains, but which acquired a bit better polish. The results show the presence of $\mathrm{Ag}$ and $\mathrm{Cl}$ (Ag 92.59 wt. \% and $\mathrm{Cl} 8.69$ wt. $\%$ on average, $n=3$, equivalent to 0.54 apfu of $\mathrm{Ag}$ and 0.46 apfu of $\mathrm{Cl}$ ). These grains may be considered as (sub)microscopic intergrowths of silver and a supergene chlorargyrite.

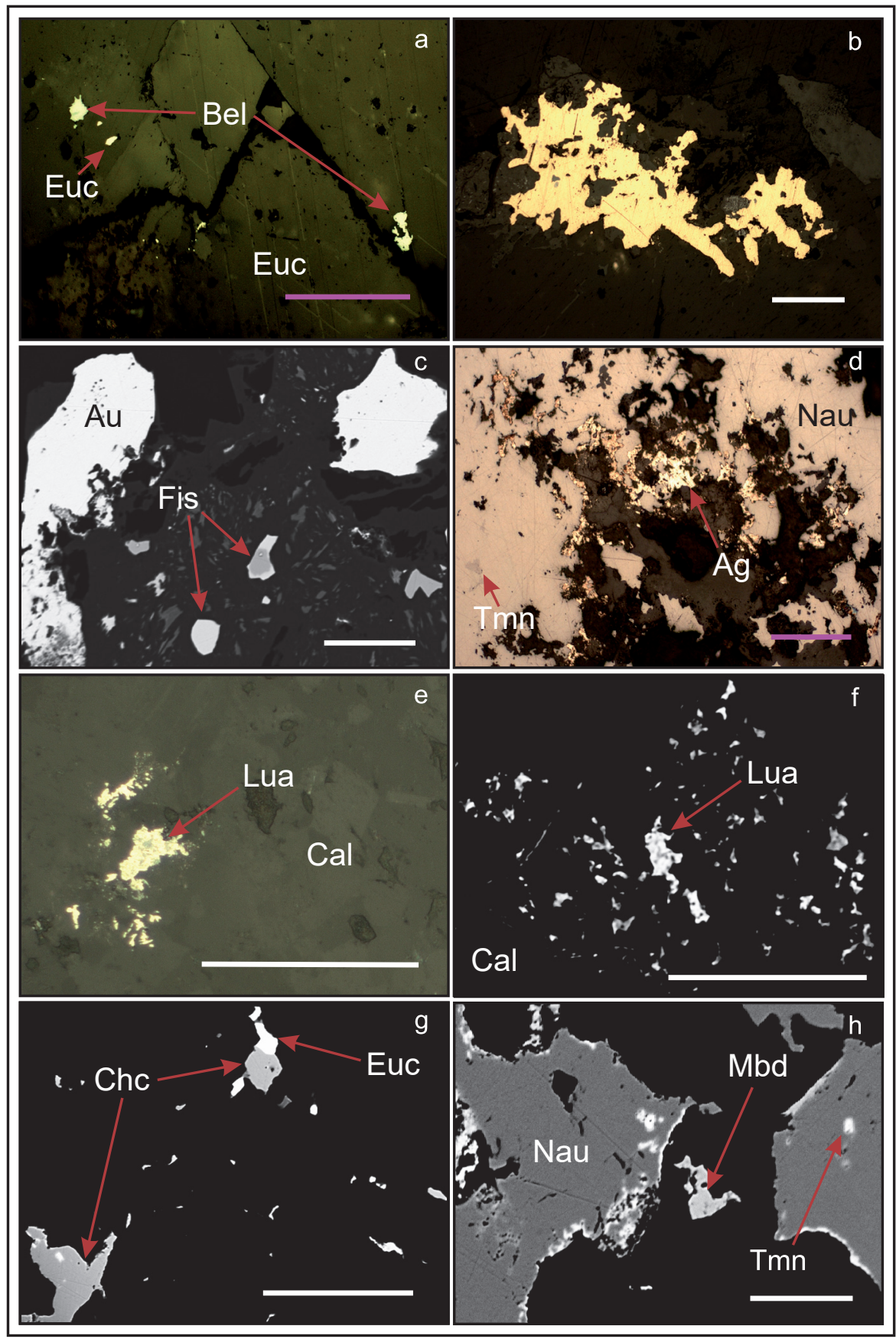

\subsubsection{Luanheite, $\mathrm{Ag}_{3} \mathrm{Hg}$}

We found a silver amalgam within the studied set of samples. Despite we were not able to determine beyond any doubt its identity, we later decided to call it luanheite. This mineral is very scarce and occurs as small grains, generally up to $10 \mu \mathrm{m}$, intergrown with $\mathrm{Ag}$, interspersed in calcite. Its color, in reflected polarized light, is similar to silver, without the pinkish tint. It is associated with a gray mineral, too small to be identifiable (Fig. 8e). The chemical composition shows the presence of sulfur, similarly to berzelianite and bellidoite we studied, but in this case, at the expense of Ag (Tab. 5). Despite this, it is consistent with the general composition of luanheite (Shao et al. 1984; Sejkora et al. 2019). The empirical formula (average of 3 analyses; on the basis of 4 apfu) is $\left(\mathrm{Ag}_{2.61} \mathrm{~S}_{0.31}\right)_{\Sigma 2.92} \mathrm{Hg}_{1.08}$. Regarding the intergrown mineral, the BSE image (Fig. 8f) shows that it looks darker than luanheite, but no other element but $\mathrm{Ag}, \mathrm{Hg}$ and $\mathrm{S}$ are present, so we specu-

Fig. 8 (a, b, d, e: photomicrography; rest: EDS images) a - bellidoite (Bel) and eucairite inclusions in calcite. $\mathbf{b}$ - gold in calcite. $\mathbf{c}$ - gold, and gold associated with fischesserite embedded in calcite. $\mathbf{d}$ - silver (Ag) included in naumannite. e, f - luanheite included in calcite. $\mathbf{g}$ - eucairite partly replaced by chalcomenite. $\mathbf{h}$ - naumannite with tiemannite and an isolated grain of molybdomenite. Scale bars equal to $50 \mu \mathrm{m}$. 
Tab. 5 Representative and average compositions of gold, silver and luanheite.

\begin{tabular}{|c|c|c|c|c|c|c|c|c|c|}
\hline & \multicolumn{3}{|c|}{ Gold } & \multicolumn{3}{|c|}{ Silver } & \multicolumn{3}{|c|}{ Luanheite } \\
\hline & 2044 & $\begin{array}{c}\text { Average } \\
n=11\end{array}$ & $\mathrm{SD}$ & 2037 & $\begin{array}{c}\text { Average } \\
n=3\end{array}$ & $\mathrm{SD}$ & 2068 & $\begin{array}{c}\text { Average } \\
n=3\end{array}$ & $\mathrm{SD}$ \\
\hline \multicolumn{10}{|l|}{ wt. \% } \\
\hline $\mathrm{Cu}$ & 0.25 & 0.20 & 0.1 & 0.86 & 0.98 & 0.1 & bdl. & 0.00 & \\
\hline $\mathrm{Ag}$ & 10.54 & 10.48 & 0.2 & 90.95 & 91.18 & 0.8 & 55.89 & 55.32 & 0.6 \\
\hline $\mathrm{Au}$ & 86.90 & 87.38 & 0.7 & bdl. & 0.00 & & bdl. & 0.00 & \\
\hline $\mathrm{Hg}$ & 2.30 & 2.42 & 0.1 & bdl. & 0.00 & & 41.40 & 42.52 & 2.1 \\
\hline $\mathrm{S}$ & bdl. & 0.00 & & bdl. & 0.00 & & 1.99 & 1.96 & 0.9 \\
\hline $\mathrm{Se}$ & bdl. & 0.00 & & bdl. & 0.00 & & bdl. & 0.00 & \\
\hline Total & 99.99 & & & 91.81 & & & 99.28 & & \\
\hline \multicolumn{10}{|l|}{ apfu } \\
\hline $\mathrm{Cu}$ & 0.01 & 0.01 & & 0.02 & 0.02 & & 0.00 & 0.00 & \\
\hline $\mathrm{Ag}$ & 0.17 & 0.17 & & 0.98 & 0.98 & & 2.63 & 2.61 & \\
\hline $\mathrm{Au}$ & 0.80 & 0.80 & & 0.00 & 0.00 & & 0.00 & 0.00 & \\
\hline $\mathrm{Hg}$ & 0.02 & 0.02 & & 0.00 & 0.00 & & 1.05 & 1.08 & \\
\hline $\mathrm{S}$ & 0.00 & 0.00 & & 0.00 & 0.00 & & 0.32 & 0.31 & \\
\hline $\mathrm{Se}$ & 0.00 & 0.00 & & 0.00 & 0.00 & & 0.00 & 0.00 & \\
\hline Total & 1.00 & 1.00 & & 1.00 & 1.00 & & 4.00 & 4.00 & \\
\hline
\end{tabular}

SD - standard deviation; bdl. - below detection limit

late that there is excess of $\mathrm{S}$ (perhaps at the expense of $\mathrm{Hg}$ ) in its structure, but the grain is too small to analyze, therefore we cannot ascertain that imiterite $\left(\mathrm{Ag}_{2} \mathrm{HgS}_{2}\right)$ is present.

\subsubsection{Malachite}

Malachite, although scarce, is ubiquitous in the veins. It occurs in filling cavities in calcite, semiradial and radial aggregates with botryoidal habit and sometimes developing thin veinlets a few micrometers thick.

\subsubsection{Chalcomenite, $\mathrm{Cu}\left(\mathrm{Se}^{4+} \mathrm{O}_{3}\right) \cdot 2 \mathrm{H}_{2} \mathrm{O}$}

This mineral is scarce and occurs in cavities forming small (up to a few $\mathrm{mm}$ ) prismatic crystals, generally grouped in clusters or partially replacing selenides (Fig. 8g). Only two analyses were performed on this mineral; both displayed low Ag contents; on average, this mineral composition indicated 52.27 $\mathrm{SeO}_{2}$ and 28.27 $\mathrm{CuO}$ wt. \%.

\subsubsection{Molybdomenite, $\mathrm{PbSe}^{4+} \mathrm{O}_{3}$}

Molybdomenite forms at the expense of clausthalite, generally developing replacement centripetal textures (Fig. $5 \mathrm{e}, \mathrm{f}$ ). It was also found as isolated, irregular grains up to $30 \mu \mathrm{m}$ (Fig. 8h). It was not possible to find enough homogeneous material to confirm the identity by the X-ray diffraction. Nevertheless, seven chemical analyses were performed. The majority of results match the theoretical composition of the mineral, although some of them show the presence of $\mathrm{Ag}$ (0.15 to 11.77 wt. $\%), \mathrm{Hg}(0.20$ to 27.01 wt. $\%$ ) or $\mathrm{Au}$ (0.62 to 5.04 wt. \%); possibly due to nanoparticle of other phases included in molybdomenite. The results of two representative analyses provided (in wt. \%): $\mathrm{PbO}$ 65.23, $\mathrm{SeO}_{2}$ 32.97, $\mathrm{Au}_{2} \mathrm{O}_{3}$ 0.70, $\mathrm{CuO} 0.12$, total 99.02 and $\mathrm{PbO} 62.35, \mathrm{SeO}_{2} 31.87, \mathrm{Au}_{2} \mathrm{O}_{3} 5.65, \mathrm{CuO}$ $0.45, \mathrm{Ag}_{2} \mathrm{O} 0.26, \mathrm{HgO} 0.21$, total 100.79.

\section{Discussion}

\subsection{Paragenetic sequence}

The Rincón Blanco occurrence is among several selenide locations from the Los Llantenes district, concentrated in a relatively small area of about $150 \mathrm{~km}^{2}$. It had been abandoned shortly after a few months of manual mining work due to the former owner's illness, but the short gallery still provides access to fresh samples of representative quality. The importance of this occurrence is not economic but mineralogical due to its diversity of rare species. We have identified eleven hypogene and three supergene Se-bearing minerals.

There are two main presentations of this paragenesis. The first occurs as discontinuous bands or clusters of grains of a millimeter to a centimeter in size, and the second occurs as fine disseminations in calcite. Naumannite, tiemannite, chrisstanleyite and jagüéite are present in both associations, while the other minerals were mainly found in the second.

It is difficult to ascertain the crystallization sequence because many of the minerals occur as isolated disseminations in calcite and the mutual contacts among them 
are limited, so we will propose a sequence based on the observed mutual relationships and the following interpolated observations and interpretations. Chrisstanleyite and jagüéite are generally intergrown, e.g., lamellae of jagüéite in chrisstanleyite (Fig. 3h), suggesting contemporaneous crystallization of both phases. The presence of a thin veinlet of tiemannite in jagüéite (Fig. 5c) filling in what appear to be intergranular cracks suggests that tiemannite postdates chrisstanleyite-jagüéite. Naumannite and tiemannite are the most abundant minerals in Rincón Blanco and they occur as homogeneous grains or, more commonly, intergrown one with the other. The frequent and intimate intergrowths of naumannite and tiemannite give the impression that they were precipitated during the same stage of the mineralization and that they are more or less coeval. We suggest that eucairite is also coeval with naumannite because there were found grains of eucairite with a naumannite disease-like texture (Fig. 5h).

Regarding clausthalite, there is evidence that it is partially replaced by tiemannite (Fig. 5e) and possibly by eucairite (Fig. 5d). Fischesserite grains were observed replacing tiemannite and thin veinlets of gold, crisscrossing a grain of tiemannite, do not continue in the replacing fischesserite (Fig. 6b). Even though gold is related to this mineral in other areas (Fig. 6a), then gold would have been formed after tiemannite, and fischesserite would have begun to form contemporary with gold and after it. The last hypogene Se-bearing minerals in the paragenesis were the copper selenides: athabascaite, berzelianite, bellidoite and umangite.

Summarizing, we assumed that the possible sequence of crystallization of the hypogene Se-bearing minerals is: chrisstanleyite-jagüéite $\rightarrow$ clausthalite $\rightarrow$ naumannitetiemannite-eucairite $\rightarrow$ fischesserite $\rightarrow$ berzelianite-bellidoite-umangite- athabascaite.

\subsection{Conditions of formation}

The conditions of formation of the Se-bearing paragenesis in Rincón Blanco require low temperatures, lower than $133^{\circ} \mathrm{C}$, because of the lack of lamellae in naumannite (Cabral et al. 2018). On the other hand, we know that berzelianite associated with bellidoite is stable below $123^{\circ} \mathrm{C}$ (Bernardini and Catani 1968; Chakrabarti and Laughlin 1981; Pirard and Hatert 2008), that the presence of umangite indicates a temperature of the formation below $112^{\circ} \mathrm{C}$ (Chakrabarti and Laughlin 1981) and that athabascaite supposedly crystallizes at temperatures below $100^{\circ} \mathrm{C}$ since attempts to synthesize this mineral (Harris et al. 1970b) were unsuccessful above that temperature.

The $\mathrm{pH}$ must have been neutral to mildly alkaline due to the abundance of calcite. The crystallization of the Se-bearing minerals formed in the early stages of the mineralization induced a decrease in the concentration of that anion and therefore an increase of the sulfur fugacity of the fluid, which would explain the relatively higher contents of sulfur in the paragenetically younger copper selenides (berzelianite, bellidoite, umangite and athabascaite). The presence of a diversity of selenides, not just of silver, in addition to the relative abundance of hematite indicates that the mineralizing fluids were highly oxidizing.

Stanley et al. (2002), based on conclusions of Tischendorf (1968, 1970, in Stanley et al. 2002), indicated that the formation of selenides, instead of sulfides, is mainly due to the high oxygen fugacity of the mineralizing fluids. Tischendorf $(1968,1970$, in Stanley et al. 2002) explains that the source of Se and the metals at Tilkerode (Harz Mountains, Germany), at least partially, could be the country-rock, a carbon-rich graptolitic black shale. We could establish a parallel with Rincón Blanco and suggest that, since the Cerro Cóndor Formation is composed of greenish and grayish schists, phyllites and metaquartzites and has a graptofauna of Glossograptus ciliatus (Aceñolaza 1970; Aceñolaza et al. 1971), it could be considered, at least in part, as the source for the Se and heavy metals forming the minerals of this paragenesis. This hypothesis should be tested by analyzing the country rocks that have not been done in this research stage.

\subsection{Similarities among other localities with Se-Pd-bearing minerals}

While Se-Pd minerals are rare, there are a few other deposits in the world with similar paragenesis. Some of them, such as the Czech deposits, include uranium as the main component (e.g., Škácha et al. 2017; Sejkora et al. 2019), or in addition to uranium there is cobalt present (for instance at Musoni Mine, DRC; Pirard and Hatert 2008), or vanadium (e.g., Velikaya Guba, Russia; Borozdin et al. 2014).

Despite these differences, there are some points that these parageneses, including those of Rincón Blanco, may have in common, such as the presence, generally abundant, of hematite, the virtual absence of sulfides, or the gangue minerals dominated by calcite. However, in Copper Hills, Australia, calcite appears to be absent and the $\mathrm{Se}-\mathrm{Pd}$-bearing minerals are closely associated with hypogene malachite (Nickel 2002).

\section{Conclusions}

Rincón Blanco is a small selenide occurrence, showing a diversity of minerals that includes eleven hypogene and three supergene Se-bearing minerals associated with precious metals.

We have proposed the following crystallization sequence of the Se-bearing minerals: chrisstanleyite-jagüéite $\rightarrow$ 
clausthalite $\rightarrow$ naumannite-tiemannite-eucairite $\rightarrow$ fischesserite $\rightarrow$ berzelianite-bellidoite-umangite- athabascaite. When oxidation processes took place, chalcomenite and molybdomenite were formed at the expense of the hypogene phases.

Based on the minerals and their associations present in Rincón Blanco, we assumed that the conditions of the mineralizing fluids include low temperatures (lower than $133^{\circ} \mathrm{C}$ to below $100^{\circ} \mathrm{C}$ ), a neutral to slightly basic $\mathrm{pH}$, high oxygen fugacity, and an increasing sulfur fugacity during the crystallization process.

Regarding the source of the Se and most of the metals involved in this paragenesis, as other authors have suggested for similar locations, it could be partly connected with the country rocks.

Acknowledgments. This study was made possible by the Argentinean support of CONICET through PIP 11220120100554-CO grant for Argentine authors and by the financial support of the Ministry of Culture of the Czech Republic (long-term project DKRVO 2019-2023/1.I.c; National Museum, 00023272) for Czech authors. Authors are grateful for the constructive review of N. Meisser. The editorial handling and comments of J. Plášil are much appreciated.

\section{References}

Aceñolaza FG (1970) Ordovician fossils from the Rio Bonete area, Department of Jagüe, Province of La Rioja, Argentina. Acta geol Lilloana 10: 315-328 (in Spanish)

AceÑolaZA FG (1971) Geología estratigráfica de la zona comprendida entre Punta del Agua y Rincón Blanco, La Rioja. Acta geol Lilloana 11: 125-150 (in Spanish)

Aceñolaza FG, Toselli AJ, Bernasconi A (1971) The Precordillera de Jagüé, La Rioja, Argentina. Its geological and structural importance. Acta geol Lilloana 11: 257-290 (in Spanish)

ANGeLelli V (1984) Metalliferous deposits of the Mineral Resources of the República Argentina II. Comisión de Investigaciones Científicas, Buenos Aires: 553-560 (in Spanish)

Bernardini GP, Catani A (1968) The Cu-Se system. Miner Depos 3: 375-380

BINDI L, CIPRIANI C (2004) Structural and physical properties of fischesserite, a rare gold-silver selenide from the De Lamar mine, Owyhee County, Idaho, USA. Canad Mineral 42: 1733-1737

Bindi L, Pratesi G (2005) Selenojalpaite, $\mathrm{Ag}_{3} \mathrm{CuSe}_{2}$, a new mineral species from the Skrikerum $\mathrm{Cu}-\mathrm{Ag}-\mathrm{Tl}$ selenide deposit, Smaland, southeastern Sweden, Canad Mineral 43: 1373-1377

Borozdin AP, PolekhovskiI YS, Bushmin SA, Glebovitski VA, Belyatski BV, Savva EV (2014) Age of metasomatism and ore formation in the Srednyaya Padma vanadium-precious metals-uranium deposit (Karelia, Baltic Shield). Dokl Earth Sci 454: 68-71

BRODTKORB MK DE (1999) The seleniferous districts of La Rioja. In: ZAPPETTINI E (ed) Mineral Resources of the República Argentina. SEGEMAR 35: 625-629 (in Spanish)

Brodtkorb MK de, Crosta S (2010) Review of the geographical location of the selenides of the Sierra de Umango, province of La Rioja. Rev Asoc Geol Argent 67: 272-279 (in Spanish)

Cabral AR, van den Kerkhof, Sosa GM, Nolte N, Liessmann W, Lehmann B (2018) Clausthalite (PbSe) and tiemannite $(\mathrm{HgSe})$ from the type locality: New observations and implications for metallogenesis in the Harz Mountains, Germany. Ore Geol Rev 102: 728-739

Cardó R, Godeas M, Márquez M, Ramallo E, ZanetTINI JC (2015) The copper metallogenetic belts of the República Argentina. SEGEMAR 53: 1-3, 19-20 (in Spanish)

Chakrabarti DJ, LaUghlin DE (1981) The Cu-Se (copperselenium) system. Bull Alloy Phase Diagrams 2: 305-315

De Montreuil LA (1975) Bellidoite: A new copper selenide. Econ Geol 70: 384-387

DoмeYкo I (1867) Mineralojia de Chile. New discoveries made in the mineral kingdom of Chile and the neighboring republics; knowledge of new mineral species, of new localities where the rarest minerals have been found, and of new analyzes. Anales de la Universidad de Chile 2: 68-74 (in Spanish)

Förster HJ, RHEde D, Tischendorf G (2004) Mineralogy of the Niederschlema-Alberoda U-Se-polymetallic deposit, Erzebirge, Germany. I. Jolliffeite, NiAsSe, the rare Se-dominant analogue of gersdorffite. Canad Mineral 42: $841-849$

Furque G (1958) El Gondwana inferior de la Precordillera septentrional (Argentina). XX Congreso Geológico Internacional Gondwana 237-256 (in Spanish)

Grundmann G, Förster HJ (2018) The Sierra de Cacheuta vein-type Se mineralization, Mendoza province, Argentina. Minerals 8: 127

Guerrero MA (1969) Cerro Cacho. Sierra de Umango. Dirección Nacional de Geología y Minería. Plan Cordillera Norte. Carpeta 1488. 190 p. Inédito. Buenos Aires (in Spanish)

HaRris DC, CABRI LJ, Kaiman S (1970a) Athabascaite: A new copper selenide mineral from Martin Lake, Saskatchewan. Canad Mineral 10: 207-215

HARRIS DC, CABRI LJ, MURRAY EJ (1970b) An occurrence of a sulphur-bearing berzelianite. Canad Mineral 10: 737-740

Johan Z, Picot P, Pierrot R, KvačeK M (1971) Fischesserite, $\mathrm{Ag}_{3} \mathrm{AuSe}_{2}$, the first selenide isotype of petzite. Bull Soc Franç Minéral Cristallogr 94: 381-384 (in French) 
Jonsson E, Högdahl K, Majka J, Murashko M (2014) Te-Cu-rich sudburyite - the first platinum-group-element mineral from the selenide mineralisation at Skrikerum, Sweden. Neues Jb Mineral Abh 191: 137-144

KrETz R (1983) Symbols for rock-forming minerals. Amer Mineral 68: 277-279

Nickel EH (2002) An unusual occurrence of Pd, Pt, Au, $\mathrm{Ag}$ and $\mathrm{Hg}$ minerals in the Pilbara Region of Western Australia. Canad Mineral 40: 419-433

Owen ND, Ciobanu CL, Cook NJ, Slattery A, Basak A (2018) Nanoscale study of clausthalite-bearing symplectites in $\mathrm{Cu}-\mathrm{Au}-(\mathrm{U})$ ores: Implications for ore genesis. Minerals 8: 67

PaAr WH, Roberts AC, Criddle AJ, Topa D (1998) A new mineral, chrisstanleyite, $\mathrm{Ag}_{2} \mathrm{Pd}_{3} \mathrm{Se}_{4}$, from Hope's Nose, Torquay, Devon, England. Mineral Mag 62: 257-264

Paar WH, Topa D, Roberts AC, Criddle AJ, Amann G, SuREDA RJ (2002) The new mineral species brodtkorbite, $\mathrm{Cu}_{2} \mathrm{HgSe}_{2}$, and the associated selenide assemblage from Tuminico, Sierra de Cacho, La Rioja, Argentina. Canad Mineral 40: 225-237

Paar WH, Topa D, Makovicky E, Sureda RJ, Brodtkorb MK de, Nickel EH, Putz H (2004) Jagüéite, $\mathrm{Cu}_{2} \mathrm{Pd}_{3} \mathrm{Se}_{4}$, a new mineral species from El Chire, La Rioja, Argentina. Canad Mineral 42: 1745-1755

PirARd C, HATERT F (2008) The sulfides and selenides of the Musonï mine, Kolwezi, Katanga, Democratic Republic of Congo. Can Mineral 46: 219-231

PouchOU JL, PICHOIR F (1985) "PAP” ( $\varphi \rho Z)$ procedure for improved quantitative microanalysis. In: ARMSTRONG
JT (ed) Microbeam Analysis. San Francisco Press, San Francisco, pp 104-106

SeJKora J, ŠKÁcha P, DolníčeK Z (2019) Ag-Bi-Hg mineralization from the deposit Brod, uranium and basemetal ore district Př́bram (Czech Republic) Bull Mineral Petrolog 27: 259-268 (in Czech)

Shao D, Zhou J, Zhang J, Bao D (1984) Luanheite - a new mineral. Acta Mineral Sinica 4: 97-101 (in Chinese)

ŠKácha P, SEJKora J, PlášIl J (2017) Selenide mineralization in the Příbram uranium and base-metal district (Czech Republic). Minerals 7(6): 91

Stanley C, Criddle AJ, Förster H-J, Roberts A (2002) Tischendorfite, $\mathrm{Pd}_{8} \mathrm{Hg}_{3} \mathrm{Se}_{9}$, a new mineral species from Tilkerode, Harz Mountains, Germany. Canad Mineral 40: 739-745

Strunz H, Nickel EH (2001) Strunz Mineralogical Tables. Chemical Structural Mineral Classification System ( $9^{\text {th }}$ ed.). E. Schweizerbart'sche Verlagsbuchhandlung, Stuttgart, Germany, pp 1-870

Tischendorf G (1968) The source of elements in the selenide mineralization at Tilkerode, Harz. Geol rud Mestorozd 10: 79-82 (in Russian)

TischendorF G (1970) The influence of the country rock on the formation of the selenide paragenesis at Tilkerode, Harz Mountains. In Problems of Hydrothermal Ore Deposits. Int Union Geol Sci (Stuttgart), Serie A 2: 316-321

WALlis W (1994) The Paragenetic and Mineralogy Research of Selenides in Harz. Unpublished Thesis, pp 1-195 